\title{
Modified agricultural waste biomass with enhanced responsive properties for metal-ion remediation: a green approach
}

\author{
Garima Mahajan · Dhiraj Sud
}

Received: 2 March 2012 / Accepted: 27 June 2012/Published online: 15 July 2012

(C) The Author(s) 2012. This article is published with open access at Springerlink.com

\begin{abstract}
Dalbergia sissoo pods, a lignocellulosic nitrogenous waste biomass, was evaluated for sequestering of $\mathrm{Cr}(\mathrm{VI})$ from synthetic wastewater. Dalbergia sissoo pods (DSP) were used in three different forms, viz. natural (DSPN), impregnated in the form of hydrated beads (DSPB), and in carbonized form (DSPC) for comparative studies. Batch experiments were performed for the removal of hexavalent chromium. Effects of $\mathrm{pH}$ adsorbent dose, initial metal-ion concentration, stirring speed, and contact time were investigated. The removal of metal ions was dependent on the physico-chemical characteristics of the adsorbent, adsorbate concentration, and other studied process parameters. Maximum metal removal for $\mathrm{Cr}(\mathrm{VI})$ was observed at $\mathrm{pH}$ 2.0. The experimental data were analyzed based on Freundlich and Langmuir adsorption isotherms. Kinetic studies indicated that the adsorption of metal ions followed a pseudo-second-order equation.
\end{abstract}

Keywords Waste water - Biosorption - Kinetics · Dalbergia sissoo $\cdot \mathrm{Cr}(\mathrm{VI})$

\section{Introduction}

Pollution of surface and ground water supplies with toxic $\mathrm{Cr}(\mathrm{VI})$ has been one of the major causes for the deterioration in water quality, as this metal is used in a number of industrial applications including steel production, electroplating, leather tanning, nuclear power plant, textile industries, wood preservation, anodizing of aluminum,

G. Mahajan $(\varangle) \cdot$ D. Sud

Department of Chemistry, Sant Longowal Institute of

Engineering and Technology, Sangrur, India

e-mail: garima8mahajan@ hotmail.com water cooling, and chromate preparation (Altundogan 2005). Chromium exists in trivalent and hexavalent forms in aquatic systems. The trivalent form at very low concentration is an essential nutrient (Rojas et al. 2005), but the hexavalent form is toxic, carcinogenic, and mutagenic in nature. It is highly mobile in soil and aquatic systems and also is a strong oxidant capable of being absorbed by the skin (Singh and Singh 2002). The hexavalent form is 500 times more toxic than the trivalent form (Kowalski 1994). Human toxicity includes lung cancer, as well as kidney, liver, and gastric damage (Cieslak-Golonka 1995). The tanning process is one of the major sources of chromium pollution at global scale. In the chromium tanning process, the leather takes up only $60-80 \%$ of the applied chromium, and the rest is usually discharged into wastewaters, causing serious environmental hazards. Chromium ion in liquid tanning wastes occurs mainly in the trivalent form, which gets further oxidized to the hexavalent form. The current drinking water guideline value for $\mathrm{Cr}(\mathrm{VI})$ recommended by the world health organization is 0.05 $\mathrm{mg} / \mathrm{L}$ (Acar and Malkoc 2004). Compliance with this strict standard is expected to be very costly and therefore, treatment efficiency is one of the major concerns for risk management when treating water containing $\mathrm{Cr}(\mathrm{VI})$. Numerous treatment methods, such as ion exchange, chemical reduction, chemical precipitation (Acar and Malkoc 2004), membrane separations (Patterson 1977 and Tiravanti et al. 1997), electrochemical precipitation (Dahbi et al. 1999), photo-catalytic reduction (Kapoor et al. 1999), adsorption (Aksu 2001; Zhang et al. 1998; Demirbas 2005) and biosorption (Goel et al. 2005 and Mohanty et al. 2006) have been tested to remove $\mathrm{Cr}(\mathrm{VI})$ from effluents to the permissible level. However, due to prohibitive cost, their use is limited in developing countries like India. Hence, there is a need to develop low-cost and easily available 
adsorbents for the removal of heavy metal ions from the aqueous environment. An abundant source of potentially metal-sorbing biomass is lingo-cellulosic agricultural waste materials. These materials could be an inexpensive substitute for the treatment of heavy-metal laden wastewater (Sud et al. 2008). Biomass is widely available, inexhaustible, and inexpensive material that exhibits significant specificity for the heavy metal ions. Dalbergia sissoo pods, an agricultural waste material, are generated in large quantities in India. These pods are put in no use and are burned in the open field, dumped in forest areas, or blown into huge piles and left to naturally deteriorate. These pods are very rich in cellulose and hemicelluloses and comprise $80 \%$ of organic matter. They contain many polymeric materials that possess functional moieties that may help for the binding of metal ions. The removal of metal ions from aqueous streams using agricultural materials is based upon metal biosorption (Volesky and Holan 1995). The basic components of the agricultural waste materials biomass include hemicellulose, lignin, extractives, lipids, proteins, simple sugars, water hydrocarbons, starch containing variety of functional groups that facilitates metal complexation which helps for the sequestering of heavy metals (Bailey et al. 1999; Hashem et al. 2005, 2006). The process of biosorption involves a solid phase (sorbent) and a liquid phase (solvent) containing a dissolved species to be sorbed. Due to high affinity of the sorbent for the metal-ion species, the latter is attracted and bound by rather complex process affected by several mechanisms involving chemisorption, complexation, adsorption on surface and pores, ion exchange, chelation, adsorption by physical forces, entrapment in inter and intrafibrillar capillaries and spaces of the structural polysaccharides network as a result of the concentration gradient and diffusion through cell wall and membrane (Bassco et al. 2002; Sarkanen and Ludwig 1971; Qaiser et al. 2007) (Fig. 1) Agricultural waste materials are usually composed of lignin and cellulose as the main constituents. Other components are hemicellulose, extractives, lipids, proteins, simple sugars, starches, water, hydrocarbons, ash and many more compounds that contain a variety of functional groups present in the binding process. Cellulose is a crystalline homo-polymer of glucose with $\beta 1 \rightarrow 4$ glycosidic linkage and intramolecular and intermolecular hydrogen bonds (Demirbas 2000a, b). Hemicellulose is a hetropolymer of mainly xylose with $\beta 1 \rightarrow 4$ glycosidic linkage with other substances of acetyl feruoyl and glycouronyl groups (Hashem et al. 2007). Lignin is three-dimensional polymer of aromatic compounds covalently linked with xylans in hardwoods and galactoglucomannans in softwoods (Garg et al. 2007; Sjötröm 1981) The functional groups present in biomass molecules acetamido groups, carbonyl, phenolic, structural polysaccharides, amido, amino, sulphydryl carboxyl groups alcohols and esters (Beveridge and Murray 1980; Gupta et al. 1999). These groups have the affinity for metal complexation. Some biosorbents are non-selective and bind to a wide range of heavy metals with no specific priority, whereas others are specific for certain types of metals depending on their chemical composition. The presence of various functional groups and their complexation with heavy metals during biosorption process has been reported by different research workers using spectroscopic techniques (Ahluwalia and Goyal 2005; Garg et al. 2007; Tarley and Arruda 2004). Various agricultural waste materials have been used, such as rice bran, rice husk, wheat bran, wheat husk, saw dust of various plants, bark of the trees, groundnut shells, coconut shells, black gram husk, hazelnut shells, walnut shells, cotton seed hulls, waste tea leaves, cassia fistula leaves, maize corn cob, jatropha de-oiled cakes, sugarcane bagasse, apple, banana, orange peels, soybean hulls, grapes stalks, water hyacinth, sugar beet pulp, sunflower stalks, coffee beans, arjun nuts, and cotton stalks, etc.(Annadurai et al. 2002; Cimino et al. 2000; Hashem et al. 2005; Macchi et al. 1986; Mohanty et al. 2005; Orhan and Bujukgungor 1993; Reddad et al. 2002; Tee and Khan 1988; Hamadi et al. 2001) A comparison of their adsorption capacities has been given in (Table 1). The present study explores the use of Dalbergia sissoo pods as sustainable adsorbent for chromium removal from aqueous systems under different experimental conditions. Experiments were performed in batch mode. Dalbergia sissoo pods were taken in three different forms, viz. natural, impregnated in form of hydrated beads, and carbonized forms. The results showed the potential removal of the $\mathrm{Cr}(\mathrm{VI})$ metal ion by biomass in matrix mode and carbon form as compared to the natural form under optimized conditions. Equilibrium and kinetic models were investigated and applied to the data to describe the overall adsorption process.

\section{Materials and methods}

\section{Preparation of adsorbent}

The selected agricultural waste material Dalbergia sissoo pods (DSP) was collected from the local area. Hot water treatment was given to them for $1 \mathrm{~h}$ to remove the soluble organic components and debris, and the material was dried at $120^{\circ} \mathrm{C}$ in hot air oven for $24 \mathrm{~h}$. The material was then ground and sieved (150 MICS). Immobilization of biomass in the form of beads was prepared by mixing sodium alginate (polymer) and biomass in different ratios of 1:1, $1: 3,1: 5,1: 7,1: 9$, and 1:11 in a pre-calculated amount of 


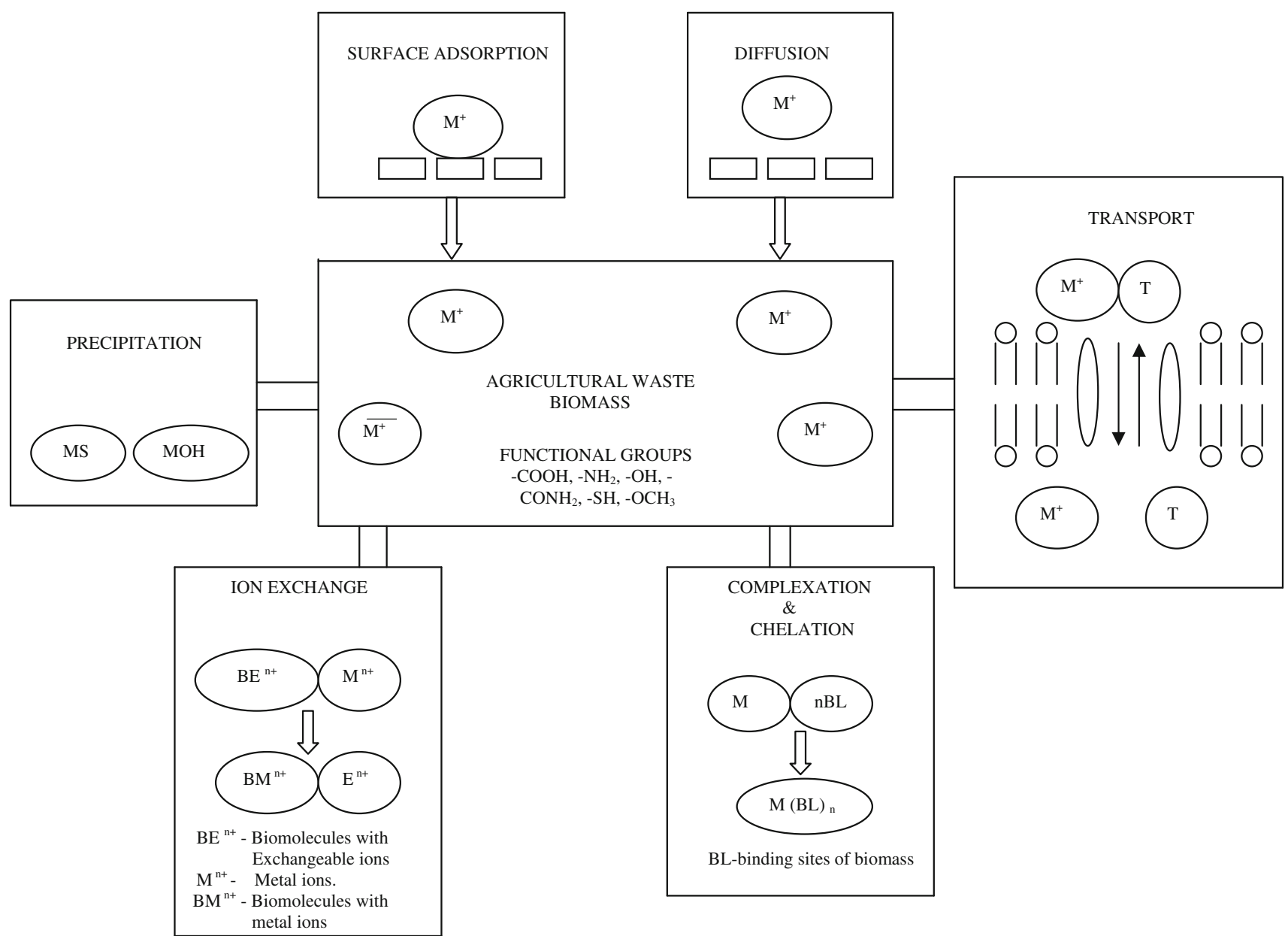

Fig. 1 Plausible mechanism of biosorption

de-ionized water and dropped into a $2 \%$ solution of calcium chloride. The beads thus prepared were stirred in the $\mathrm{CaCl}_{2}$ solution for $24 \mathrm{~h}$ for hardening. Beads were then washed three times with de-ionized water and maintained in $2 \% \mathrm{CaCl}_{2}$ solution at $4{ }^{\circ} \mathrm{C}$. The surface area of the beads was found to be $50.2 \times 10^{-3} \mu \mathrm{m}$. The carbonized form of the biomass was prepared by heating the powder of biomass in a muffle furnace at $800{ }^{\circ} \mathrm{C}$ for $2 \mathrm{~h}$.

\section{Preparation of adsorbate}

A stock solution of chromium (VI) $(1,000 \mathrm{mg} / \mathrm{L})$ was prepared by dissolving potassium dichromate in doubledistilled water. The stock solution was diluted with distilled water to obtain $\mathrm{Cr}(\mathrm{VI})$ solutions of the desired concentration range. The $\mathrm{pH}$ of the solutions was adjusted using $0.01 \mathrm{M} \mathrm{NaOH} / 0.01 \mathrm{M} \mathrm{HCl}$ using an Orion 420A pH meter. The $\mathrm{Cr}(\mathrm{VI})$ concentration was determined spectrophotometrically [Double Array UV-Vis Spectrophotometer,
Agilent 8453 ] by the diphenyl-carbazide method (Zhang et al. 1998).

\section{Experimental setup}

Adsorption experiments were carried out using $100 \mathrm{~mL}$ of chromium solution of the desired concentration $(50 \mathrm{mg} / \mathrm{L})$ at an initial $\mathrm{pH}$ of 2.0 and with $1.5 \mathrm{~g}$ of adsorbent in a $250 \mathrm{~mL}$ Erlenmeyer flask at $25 \pm 1{ }^{\circ} \mathrm{C}$ (stirring speed $250 \mathrm{rpm}$ ). At predetermined time intervals (60 min), samples were separated by centrifugation at $4,000 \mathrm{rpm}$ for $10 \mathrm{~min}$. The residual chromium concentration in the supernatant was determined as given earlier. All experiments were replicated three times for all the forms of adsorbents. The removal percentage $(R \%)$, defined as the ratio of difference in metal concentration before and after adsorption $\left(C_{\mathrm{i}}-C_{\mathrm{e}}\right)$ to the initial concentration of chromium in the aqueous solution $\left(C_{\mathrm{i}}\right)$, was calculated using Eq. 1: 
Table 1 Various agricultural products as biosorbents and their sorption potential

\begin{tabular}{lll}
\hline Agricultural waste biomass & Percentage of removal (\%) & References \\
\hline Oat biomass & $>80$ & Gardea-Torresdey et al. \\
& & $(2000)$ \\
Formaldehyde treated saw dust Indian rosewood & $62-86$ & Garg et al. (2004) \\
Beech saw dust & 100 & Acar and Malkoc (2004) \\
Chemically treated Bagasse & $50-60$ & Krishanani et al. (2004) \\
Formaldehyde treated rice husk & 88.88 & Bishnoi et al. (2004) \\
Bagasse fly ash & $96-98$ & Gupta and Ali (2004) \\
Wheat bran & $>82$ & Farajzadeh and Monji (2004) \\
Coconut shell fibers & $>80$ & Mohan et al. (2006) \\
Commercial granular activated carbon $(\mathrm{C} 2$ and C3) & $93-98$ & Fahim et al. (2006) \\
and AC of waste from sugar industry $(\mathrm{C} 1)$ & $\mathrm{C} 1>\mathrm{C} 2>\mathrm{C} 3$ & Sarin and Pant (2005) \\
Eucalyptus bark & Almost 100 & Venkateswarlu et al. (2007) \\
Neem leave powder & $>96$ & Karthikeyan et al. (2005) \\
Rubber wood saw dust & $60-70$ & Rao et al. (2002) \\
Pretreated bagasse with NaOH and $\mathrm{CH}_{3} \mathrm{COOH}$ & 90,67 & Gupta et al. (1999) \\
Modified bagasse fly ash & 67 & Valix et al. (2006) \\
Activated carbon from bagasse (carbonization and gasification) & Significant metal uptake & Garg et al. (2007) \\
Sugarcane bagasse, maize corn cob, jatropha oil cake & $40-50$ & Oliveira et al. (2005) \\
Raw rice bran & &
\end{tabular}

Table 2 Structural composition of Dalbergia sissoo pods

\begin{tabular}{ll}
\hline Structural components & Percentage (\%) \\
\hline Carbon & 52.71 \\
Nitrogen & 6.23 \\
Hydrogen & 5.17 \\
Cellulose & 29 \\
Hemi-cellulose & 07 \\
Lignin & 22 \\
Carbohydrate & 16 \\
Crude Protein & 14 \\
Fiber & 21 \\
Ash & 18 \\
\hline
\end{tabular}

Table 3 FT-IT spectra of adsorbent and Cr(VI) treated adsorbent

\begin{tabular}{llllll}
\hline Adsorbent & \multicolumn{5}{l}{ Band positions $\left(\mathrm{cm}^{-1}\right)$} \\
\cline { 2 - 6 } & $\mathrm{O}-\mathrm{H}$ & $\mathrm{C}-\mathrm{H}$ & $\mathrm{C}=\mathrm{O}$ & $\mathrm{OCH}_{3}$ & Bending vibrations \\
\hline DSP native & $3,083.6$ & $2,922.3$ & $1,739.2$ & $1,055.7$ & 614.5 \\
DSP-Cr(VI) & $3,356.8$ & $2,919.2$ & $1,735.8$ & $1,154.2$ & $896.6,614$
\end{tabular}

$R(\%)=\frac{C_{\mathrm{i}}-C_{\mathrm{o}}}{C_{\mathrm{i}}} \times 100$.

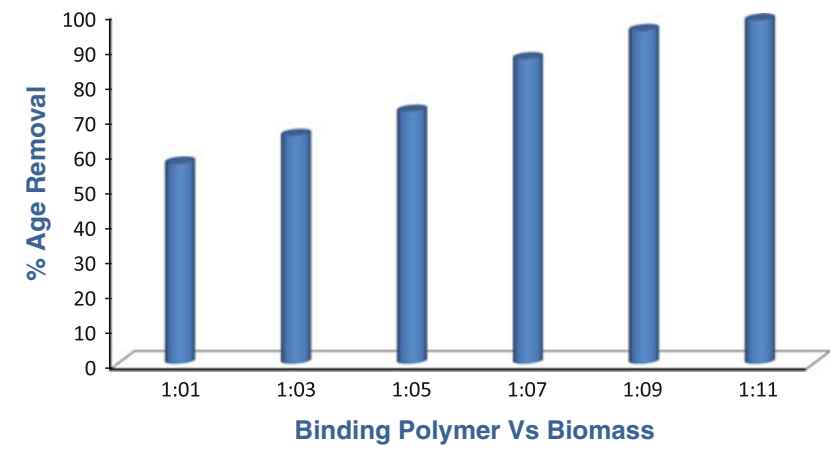

Fig. 2 Binding agent and biomass ratio

\section{Results and discussion}

Structural composition

In terms of their structure, Dalbergia sissoo pods (DSP) can be regarded as a lingo-cellulosic agricultural waste material containing high amount of proteins and crude fibers (Table 2). The pods are extremely rich in the nitrogenous substances containing various functional moieties for sequestering of heavy metal ions. The mechanism of $\mathrm{Cr}(\mathrm{VI})$ removal by lingo-cellulosic biomass is attributed to anionic adsorption or by reduction of $\mathrm{Cr}(\mathrm{VI})$ to $\mathrm{Cr}(\mathrm{III})$ by ligno-cellulosic biomass. The contributing functional 
groups such as phenolic methoxyl and hydroxyl groups of lignin are responsible for $\mathrm{Cr}(\mathrm{VI})$ reduction and the oxidation of these functional groups gives rise to the formation of carbonyl and carboxyl groups of lingo-cellulosic material. In addition to forming surface complexes, a portion of $\mathrm{Cr}(\mathrm{III})$ bound to ligno-cellulosic materials also formed a hydroxide precipitate. FT-IR analysis of the adsorbent before and after sorption of metal ions was performed to determine the vibrational frequency changes in the functional groups of the adsorbent in various forms. The spectra of adsorbents were measured in the range of $500-4,000 \mathrm{~cm}^{-1}$ wave number. The FT-IR spectra showed a number of adsorption peaks, indicating the complex nature of the studied adsorbent. In Dalbergia sissoo pods (DSP), the sorption peak at $3,083.6 \mathrm{~cm}^{-1}$ indicates the existence of free and intermolecular-bonded hydroxyl groups. The peaks observed at $2,922.3 \mathrm{~cm}^{-1}$ can be assigned to the stretching vibration of the $\mathrm{C}-\mathrm{H}$ group. The peaks around $1,739.2 \mathrm{~cm}^{-1}$ correspond to the $-\mathrm{C}=\mathrm{O}$ group. The strong $\mathrm{C}-\mathrm{O}$ band at $1,055.7 \mathrm{~cm}^{-1}$ due to $-\mathrm{OCH}_{3}$ groups also confirms the presence of lignin structures in Dalbergia sissoo pods. The $\mathrm{C}-\mathrm{O}$ absorption peak was observed to shift to $1,154.2 \mathrm{~cm}^{-1}$ when DSP was loaded with chromium. It seems that this functional group participates in metal binding. Table 3 presents the fundamental peaks of the adsorbent before and after use. The spectra display a number of absorption peaks indicating the complex nature of the examined adsorbent.

\section{Effect of polymer and biomass ratio}

For the formation of beads, biomass was bonded with sodium alginate in the ratio $1: 9$ of binding agent to biomass. This particular ratio was selected after a series of trials with different ratios of 1:1, 1:3, 1:5, 1:7, 1:9 and $1: 11$. The adsorption increased with increase in the ratio of biomass to binding agent. Maximum adsorption was achieved with a ratio of $1: 9$, as compared to $1: 11$, which was attributed to a lack of stability in the latter; hence, the adsorption experiments were further performed with beads prepared by using the ratio 1:9 (Fig. 2).

\section{Effect of $\mathrm{pH}$}

$\mathrm{pH}$ is an important controlling parameter in the adsorption process due to its influence on the surface properties of the adsorbent and the ionic form of the metal ion in solution. Adsorption experiments were carried out in the $\mathrm{pH}$ range 2-10 (Although it was found that after $\mathrm{pH}$ 7 , solution gets precipitated, thus studies were limited up to $7 \mathrm{pH}$ only.), while keeping all other parameters constant (chromium concentration $=50 \mathrm{mg} / \mathrm{L}$; stirring

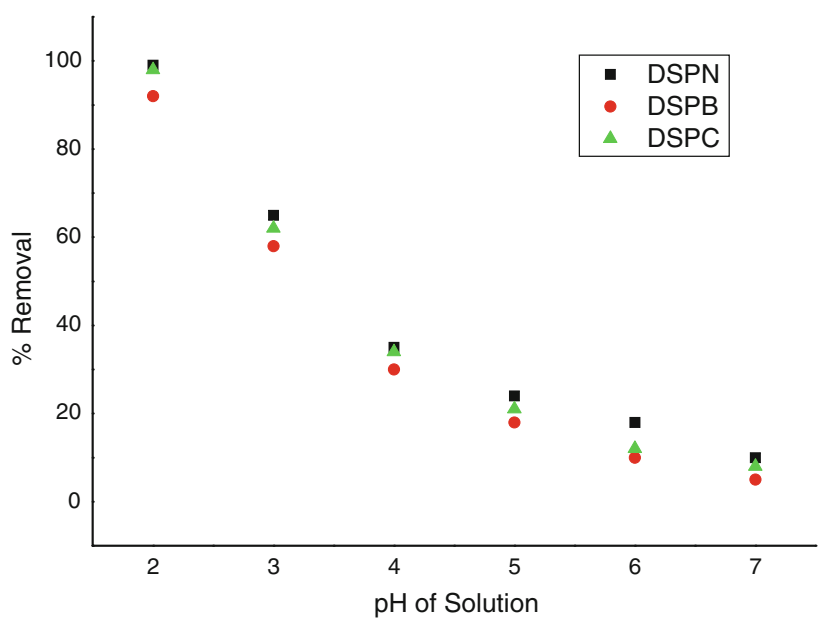

Fig. 3 Effect of $\mathrm{pH}$ on chromium removal by different forms of adsorbent $(\mathrm{Cr}$ conc. $=50 \mathrm{mg} / \mathrm{L}$; stirring speed $=250 \mathrm{rpm}$; contact time $=60$ and $30 \mathrm{~min}$; adsorbent dose $=15,12$, and $5 \mathrm{~g} / \mathrm{L}$ (DSPN, DSPB, DSPC)

speed $=250 \mathrm{rpm} ; \quad$ contact time $=60 \mathrm{~min}$, adsorbent dose $=15 \mathrm{~g} / \mathrm{L}$, temp. $=25^{\circ} \mathrm{C}$ ). The $\mathrm{pH}$ of the chromium solution was adjusted after adding the adsorbent. The maximum adsorption of chromium was 99,98 , and $92 \%$ for DSPC, DSPB, and DSPN, respectively at $\mathrm{pH} 2$ (Fig. 3). There was a sharp decline in percent adsorption with increase in $\mathrm{pH}$ of the aqueous solution. Chromium adsorption by DSPN was decreased from 92 to $25 \%$ as the $\mathrm{pH}$ was increased from 2 to 5 . Chromium adsorption by DSPB was decreased from 98 to $28 \%$ as $\mathrm{pH}$ was increased from 2 to 5 . Similarly, chromium adsorption by DSPC was decreased from 99 to $45 \%$ as $\mathrm{pH}$ was increased from 2 to 5 . Maximum adsorption was observed at $\mathrm{pH} 2.0$, and hence it was taken as the optimal $\mathrm{pH}$ value for further adsorption experiments. Our results are consistent with those of other workers (Kapoor et al. 1999; Aksu 2001; Zhang et al. 1998; Goel et al. 2005; Mohanty et al. 2005; Hamadi et al. 2001; Garg et al. 2004) who observed that the removal of $\mathrm{Cr}(\mathrm{VI})$ decreases with the increase of $\mathrm{pH}$. The $\mathrm{pH}$ dependence of metal adsorption can largely be related to the type and ionic state of the functional groups present on the adsorbent and the metal chemistry in solution (Mohanty et al. 2006). In the $\mathrm{pH}$ range of 1.0-6.0, chromium ions co-exist in different forms, such as $\mathrm{Cr}_{2} \mathrm{O}_{7}{ }^{-}, \mathrm{HCrO}_{4}{ }^{-}, \mathrm{Cr}_{3} \mathrm{O}_{10}{ }^{2-}$, and $\mathrm{Cr}_{4} \mathrm{O}_{13}{ }^{2-}$, of which $\mathrm{HCrO}_{4}{ }^{-}$predominates. As the $\mathrm{pH}$ of the solution increases, the predominant species become $\mathrm{CrO}_{4}{ }^{2-}$ and $\mathrm{Cr}_{2} \mathrm{O}_{7}{ }^{2-}$. More adsorption at acidic $\mathrm{pH}$ suggests that the lower $\mathrm{pH}$ results in an increase in $\mathrm{H}^{+}$ions associated with the adsorbent surface, resulting in sufficiently strong electrostatic attraction between a positively charged adsorbent surface and negatively charged chromate ions. Lesser adsorption of $\mathrm{Cr}(\mathrm{VI})$ at $\mathrm{pH}$ values greater than 6.0 
may be due to the dual competition of both the anions $\mathrm{CrO}_{4}{ }^{2-}$ and $\mathrm{OH}^{-}$to be adsorbed on the surface of the adsorbent, noting that $\mathrm{OH}^{-}$adsorption is favored by higher $\mathrm{pH}$. This is in accordance with the earlier studies that have reported the removal of $\mathrm{Cr}(\mathrm{VI})$ by different adsorbents (Mohanty et al. 2005).

\section{Adsorption kinetics}

Studies comparing the three forms of biosorbents were conducted by varying the contact time from 5 to $120 \mathrm{~min}$ at a fixed initial chromium concentration $(50 \mathrm{mg} / \mathrm{L})$, stirring speed $(250 \mathrm{rpm})$, temperature $\left(25^{\circ} \mathrm{C}\right)$, and $\mathrm{pH}(2.0)$. Maximum chromium was sequestered from the solution within $60 \mathrm{~min}$ by the different forms of adsorbent (Fig. 4). The chromium removal was $99 \%$ by DSPC, $98 \%$ by DSPB, and $92 \%$ by DSPN within 60 min of contact time. In the case of DSPC, there was very fast adsorption, so keeping these observations in view, 30 min contact time was chosen for DSPC and $60 \mathrm{~min}$ for the DSPB and DSPN forms for further experiments.

\section{Effect of adsorbent dose}

The percent adsorption of $\mathrm{Cr}(\mathrm{VI})$ on different forms of adsorbent was studied at different adsorbent doses $(250,500,1,000,1,500$ and $2,000 \mathrm{mg} / 100 \mathrm{~mL}$, respectively), keeping chromium concentration $(50 \mathrm{mg} / \mathrm{L})$, stirring speed $(250 \mathrm{rpm}), \mathrm{pH}(2.0)$, temperature $\left(25^{\circ} \mathrm{C}\right)$, and contact time (30 and $60 \mathrm{~min}$ as obtained by kinetic studies) constant. The results showed that with increase in the adsorbent dose, the percentage adsorption of chromium

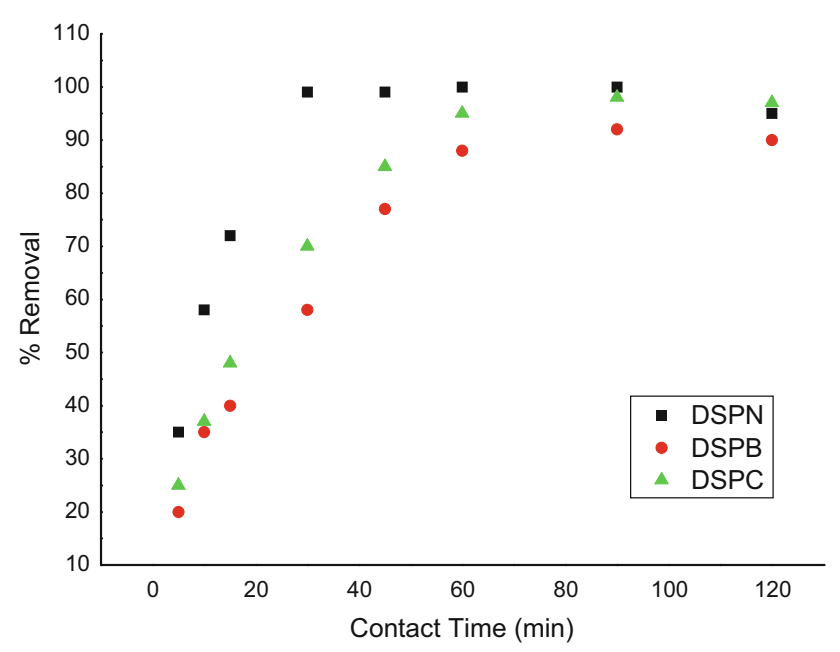

Fig. 4 Effect of contact time (min) of chromium on its removal by different forms of adsorbents (adsorbent dose $=15,12,5 \mathrm{~g} / \mathrm{L}$ ) chromium concentration $=50 \mathrm{mg} / \mathrm{L}$, stirring speed $=250 \mathrm{rpm}, \mathrm{pH}$ 2.0, and temperature $=25^{\circ} \mathrm{C}$ )

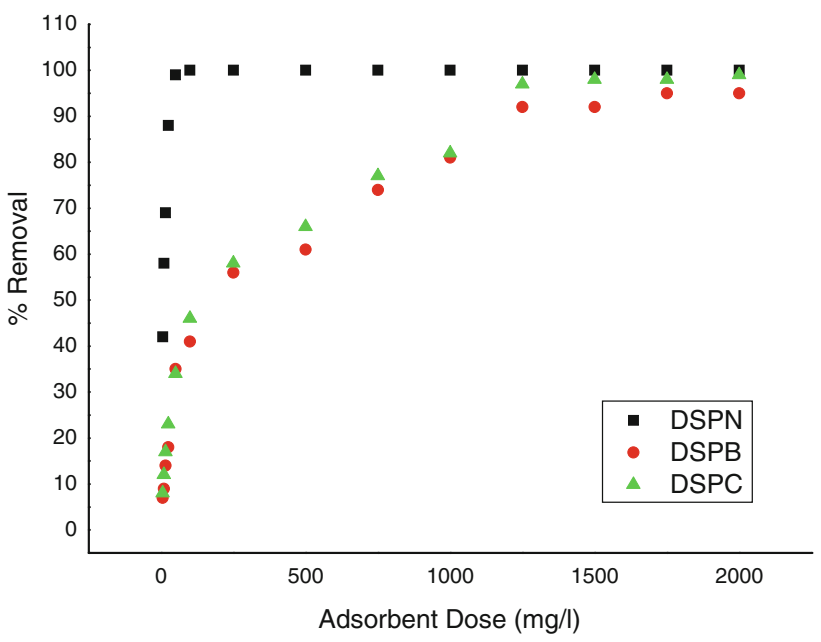

Fig. 5 Effect of adsorbent dose on chromium removal by different forms of adsorbent (chromium conc. $=50 \mathrm{mg} / \mathrm{L}$; stirring speed $=250 \mathrm{rpm} ; \quad$ pH $2.0 ; \quad$ temperature $=25^{\circ} \mathrm{C}$ and contact time $=60$ and $30 \mathrm{~min}$ )

was increased, and the maximum removal was observed with adsorbent dose of $5.0 \mathrm{~g} / \mathrm{L}$ of DSPC, $12 \mathrm{~g} / \mathrm{L}$ of DSPB, and $15 \mathrm{~g} / \mathrm{L}$ of DSPN (Fig. 5). Increase in the percentage adsorption with adsorbent dose may be due to the increase in adsorbent surface area and availability of more adsorption sites (Mohanty et al. 2005). However, unit adsorption was decreased with increase in adsorbent dosage. As the adsorbent dose was increased from 2.5 to $20.0 \mathrm{~g} / \mathrm{L}$, the unit adsorption for DSPC, DSPB, and DSPN was decreased significantly. In the case of DSPN, it decreased from 1.74 to 0.30 . This may be due to overlapping of adsorption sites as a result of overcrowding of adsorbent particles

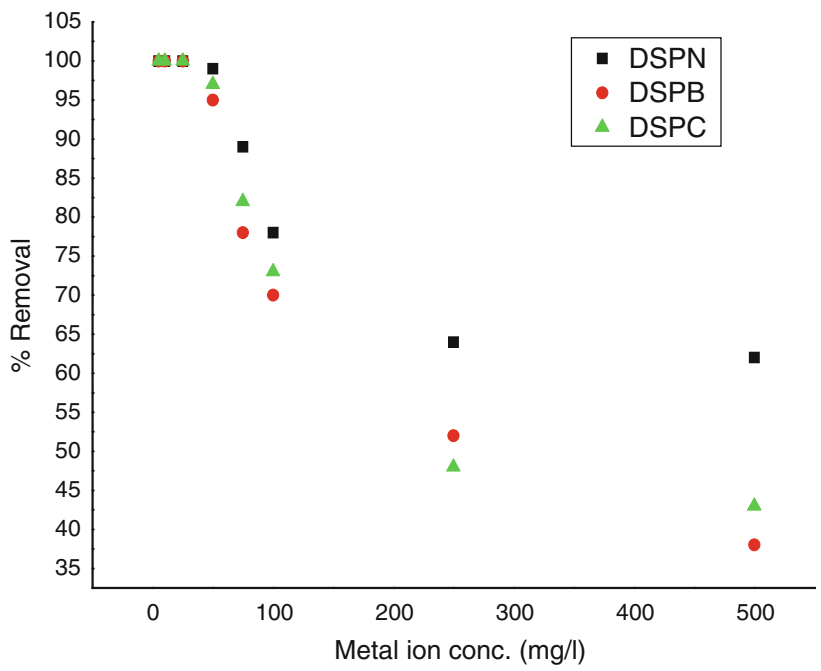

Fig. 6 Effect of initial concentration of chromium on its removal by different forms of adsorbent (adsorbent dose $=20 \mathrm{~g} / \mathrm{L}$, stirring speed $=250 \mathrm{rpm}, \quad \mathrm{pH} 2.0$, temperature $=25^{\circ} \mathrm{C}$, and contact time $=60 \mathrm{~min})$ 


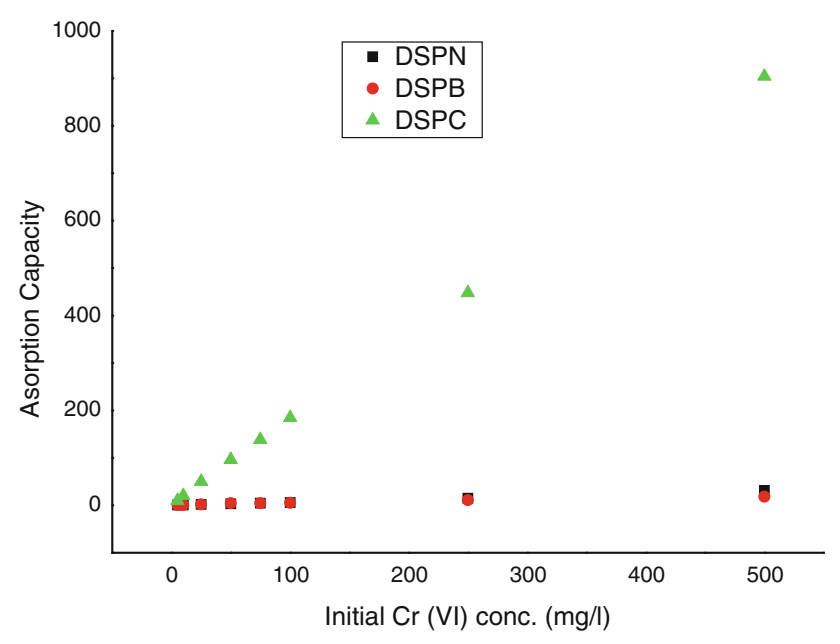

Fig. 7 Effect of adsorption of chromium per unit mass of adsorbent

Table 4 Adsorption capacity of different forms adsorbent at different initial chromium concentration

\begin{tabular}{lccc}
\hline $\begin{array}{l}\text { Initial chromium } \\
\text { concentration }\left(\mathrm{mg} \mathrm{L}^{-1}\right)\end{array}$ & $\begin{array}{l}\mathrm{DSPN}\left(Q_{\mathrm{e}}\right) \\
\left(\mathrm{mg} \mathrm{g}^{-1}\right)\end{array}$ & $\begin{array}{l}\mathrm{DSPB}\left(Q_{\mathrm{e}}\right) \\
\left(\mathrm{mg} \mathrm{g}^{1}\right)\end{array}$ & $\begin{array}{l}\mathrm{DSPC}\left(Q_{\mathrm{e}}\right) \\
\left(\mathrm{mg} \mathrm{g}^{-1}\right)\end{array}$ \\
\hline 5 & 0.412 & 0.417 & 12 \\
10 & 0.758 & 0.849 & 21 \\
25 & 1.921 & 2.182 & 54 \\
50 & 3.62 & 4.252 & 97 \\
75 & 4.69 & 4.428 & 142 \\
100 & 5.85 & 05.12 & 188 \\
250 & 15.27 & 12.186 & 452 \\
500 & 32.42 & 19.10 & 912 \\
\hline
\end{tabular}

(Namasivayam et al. 1998). The order of percentage removal of chromium by studied adsorbent forms was: DSPC $>$ DSPB $>$ DSPN.

\section{Effect of initial concentration}

The percent adsorption of $\mathrm{Cr}(\mathrm{VI})$ with different adsorbents was studied by varying the chromium concentration $(5,10$, $25,50,75,100,250$, and $500 \mathrm{mg} / \mathrm{L})$, while keeping the adsorbent dose (15 g/L of DSPN, $12 \mathrm{~g} / \mathrm{L}$ of DSPB, $5 \mathrm{~g} / \mathrm{L}$ of DSPC), stirring speed (250 rpm), $\mathrm{pH}$ (2.0), temperature $\left(25^{\circ} \mathrm{C}\right)$, and contact time (60 and $\left.30 \mathrm{~min}\right)$ constant. Higher concentrations of metal ions were used to study the maximum adsorption capacity of the adsorbents (Mohanty et al. 2006; Karthikeyan et al. 2005; Garg et al. 2007, 2008). The percent chromium adsorption was decreased with increase in initial chromium concentration (Fig. 6). However, the actual amount of chromium adsorbed per unit mass of the adsorbent was increased with increase in chromium concentration in the test solution (Fig. 7). As the chromium concentration in the test solution was increased from 5.0 to
$500 \mathrm{mg} / \mathrm{L}$, the unit adsorption of chromium on DSPC, DSPB, and DSPN increased from 12.00 to $912,0.417$ to 19.10 , and 0.412 to $32.42 \mathrm{mg} \mathrm{g}^{-1}$, respectively (Table 4). The adsorption capacity of an adsorbent, which is obtained from the mass balance on the sorbate in a system with solution volume $V$, is often used to acquire the experimental adsorption isotherms. Under the experimental conditions, the adsorption capacities of all the adsorbents for each concentration of chromium (VI) ions at equilibrium were calculated from the following equation (Goel et al. 2005)

$q_{\mathrm{e}}\left(\mathrm{mg} \mathrm{g}^{-1}\right)=\left[\frac{C_{\mathrm{i}}-C_{\mathrm{e}}}{M}\right] \times V$

where $C_{\mathrm{i}}$ is the initial concentration in at equilibrium, $V$ is the volume of solution (in L), and $M$ is the mass of the adsorbent. The order of percentage removal of chromium for different metal-ion concentration was DSPC > DSPB > DSPN.

\section{Adsorption isotherms}

The analysis of equilibrium data is important for developing an equation that can be used for design purposes. The simplest adsorption isotherm is based on the assumptions that every adsorption site is equivalent and the ability of a particle to bind is independent of whether or not adjacent sites are occupied. Classical adsorption models, such as the Langmuir and Freundlich models, have been extensively used to describe the equilibrium established between adsorbed metal ions on the biomass $\left(q_{\mathrm{e}}\right)$ and metal ions remaining in solution $\left(C_{\mathrm{e}}\right)$ at a constant temperature. The experimental results obtained for the adsorption of chromium on DSPC, DSPB, and DSPN at constant temperature $\left(25 \pm 1{ }^{\circ} \mathrm{C}\right)$ under pre-defined conditions of $\mathrm{pH}$, adsorbent dose, and stirring speed obeyed the Freundlich adsorption isotherm. The Freundlich isotherm represents the relationship between the amount of metal adsorbed per unit mass of the adsorbent $(x / m)$ and concentration of the metal ion in solution at equilibrium $\left(C_{\mathrm{e}}\right)$,

$\log \frac{x}{m}=\log K_{\mathrm{f}}+\frac{1}{n} \log C_{\mathrm{e}}$

where $K_{\mathrm{f}}\left(\mathrm{L} \mathrm{g} \mathrm{g}^{-1}\right)$ is an indicator of adsorption capacity and $n$ (dimensionless) indicates the effect of concentration on the adsorption capacity and represents the adsorption intensity (dimensionless). The plot of $\log (x / m)$ versus $\log$ $C_{\mathrm{e}}$ for various initial concentrations was linear (figures not given), indicating the applicability of the classical adsorption isotherm to the DSPC-Cr(VI), DSPB-Cr(VI), and DSPN-Cr(VI) systems. The adsorption capacities $\left(K_{\mathrm{f}}\right)$ and the Freundlich constant $(n)$ are given in Table 5. 
Table 5 Freundlich and Langmuir models regression constants for different forms of adsorbents

\begin{tabular}{lllllllll}
\hline Biosorbent & \multicolumn{2}{l}{ Freundlich Isotherm } & & \multicolumn{2}{l}{ Langmuir Isotherm } \\
\cline { 2 - 3 } & $\begin{array}{l}K_{\mathrm{f}} \\
\left(\mathrm{L} \mathrm{g}^{-1}\right)\end{array}$ & $N$ & $R^{2}$ & & $\begin{array}{l}Q_{\mathrm{o}} \\
\left(\mathrm{mg} \mathrm{g}^{-1}\right)\end{array}$ & $b\left(\mathrm{mg}^{-1}\right)$ & $R^{2}$ \\
\hline DSPN & 0.6852 & 1.012 & 0.7262 & 2.82 & 0.04255 & 0.8021 \\
DSPB & 0.7218 & 0.0016 & 0.9821 & 3.52 & 0.0482 & 0.8912 \\
DSPC & 1.1027 & 0.0017 & 0.9027 & 1.47 & 0.0210 & 0.9842 \\
\hline
\end{tabular}

The Langmuir isotherm is valid for monolayer adsorption onto a surface containing a finite number of identical sites. The model assumes uniform energies of adsorption on to the surface and no transmigration of adsorbate in the plane of the surface. The Langmuir isotherm is represented by the following equation,

$\frac{c_{\mathrm{e}}}{q_{\mathrm{e}}}=\frac{1}{Q_{0} b}+\frac{c_{\mathrm{e}}}{Q_{\mathrm{e}}}$

where $C_{\mathrm{e}}$ is the equilibrium concentration $(\mathrm{mg} / \mathrm{L}), q_{\mathrm{e}}$ the amount adsorbed at equilibrium time $\left(\mathrm{mg} \mathrm{g}^{-1}\right)$ and $Q_{\mathrm{o}}$ and $b$ are the maximum quantity of metal ions per unit weight of biomass to form a complete monolayer on the surface $\left(\mathrm{mg} \mathrm{g}^{-1}\right)$, whereas $b$ is a constant related to the affinity of binding sites with the metal ions $\left(1 \mathrm{mg}^{-1}\right)$. The plots of $C_{\mathrm{e}} /$ $(x / m)$ versus $C_{\mathrm{e}}$ are linear, which shows that the adsorption of $\mathrm{Cr}(\mathrm{VI})$ follows a Langmuir isotherm model. The correlation coefficient $(r)$ values were very high for all the adsorbents (Table 5) which indicates that the data fitted reasonably well to the Langmuir isotherm in the present adsorption studies. Value of slope found to be lesser than unity implied that significant adsorption took place at low metal-ion concentration.

\section{Adsorption kinetics}

Pseudo first- and second-order equations

The kinetics of adsorption is important, as it controls the process efficiency. For evaluating the adsorption kinetics of heavy metals, the pseudo-first order equation of Lagergren has been used to test experimental data,

$\ln \left(Q_{\mathrm{e}}-Q_{\mathrm{t}}\right)=\ln Q_{\mathrm{e}}-K_{1} t$

where $Q_{\mathrm{e}}(\mathrm{mg} / \mathrm{g})$ and $Q_{\mathrm{t}}(\mathrm{mg} / \mathrm{g})$ are the amount adsorbed of heavy metal ions at equilibrium and at time $t$, respectively, and $K_{1}\left(\mathrm{~min}^{-1}\right)$ is the rate constant of pseudo first-order adsorption. The application of this equation to the data of selected biosorbent (data not shown) indicated the inapplicability of the model.

The pseudo second-order kinetic model is linearly expressed as Ho and Mckay (1998). $t / Q_{\mathrm{t}}=1 / K_{2} Q_{\mathrm{e}}^{2}+t / Q_{\mathrm{e}}$

where $K_{2}(\mathrm{~g} / \mathrm{mg} \mathrm{min})$ is the pseudo second-order rate constant, which can be calculated from the intercept of the straight line obtained from plotting $t / Q_{\mathrm{t}} V_{\mathrm{s} t}$. In addition, the initial sorption rate can be calculated using the relation (Koynucu 2008):

$K_{\mathrm{o}}=K_{2} Q_{\mathrm{e}}^{2}$

The perfect fit of the experimental data of DSP indicates the applicability of model for the adsorption of heavy metal ions on the selected biosorbent.

\section{Film diffusion studies}

Mass transfer plays an important role in sequestering of heavy metal from aqueous solution by the sorption process on the solid materials. In the present study, the mass transfer has been studied according to the model (Eq. 8) suggested by Mckay et al. assuming diffusion resistance within the particle to be negligible.

$\ln \left(\frac{C_{\mathrm{t}}}{C_{0}}-\frac{1}{1+m k}\right)=\ln \frac{m k}{1+m k}-\frac{1+m k}{m k} \cdot \beta_{\mathrm{L}} \cdot S_{\mathrm{S}} \cdot t$

where $C_{\mathrm{t}}$ and $C_{0}$ (both in $\mathrm{mg} \mathrm{g}^{-1}$ ) are the respective concentrations of $\mathrm{Cr}(\mathrm{VI})$ ions at any time $t$ and $t=0$; $k\left(1 \mathrm{~g}^{-1}\right)$ is the product of $Q_{0}$ and $b$ and is known as Langmuir's constant; $m\left(\mathrm{~g} \mathrm{l}^{-1}\right)$ is the mass of adsorbent particles per unit volume, and $S_{\mathrm{s}}\left(\mathrm{cm}^{-1}\right)$ is the outer area of the adsorbent per unit volume. The mass of $m$ and $S_{\mathrm{s}}$ were calculated using Eqs. (9) and (10).

$m=\frac{W}{V}$

and

$S_{\mathrm{s}}=\frac{6 m}{d_{\mathrm{p}} \rho p\left(1-\varepsilon_{\mathrm{p}}\right)}$

where $W(\mathrm{~g})$ is the weight of the adsorbent, $V$ is the volume of the particle-free solution; $d_{\mathrm{p}}(\mathrm{cm})$ is the particle diameter, $\rho_{\mathrm{p}}$ is the density of the adsorbent and $\varepsilon_{\mathrm{p}}$ is the porosity of the particles. The value of $k\left(1 \mathrm{~g}^{-1}\right)$ in Eq. (8) was calculated using Eq. (11).

$k=Q^{0} b_{\mathrm{s}}$

where $Q_{0}$ and $b$ are the same terms as those used in Langmuir's model; $k$ is also regarded as Langmuir's constant. The curve was found linear up to $60 \mathrm{~min}$; this implies that throughout the process film diffusion plays a significant role in the adsorption of $\mathrm{Cr}(\mathrm{VI})$ from aqueous solution onto the studied adsorbents. The mass transfer coefficient $\beta_{\mathrm{L}}$ was calculated by multiplying the slope and intercept 


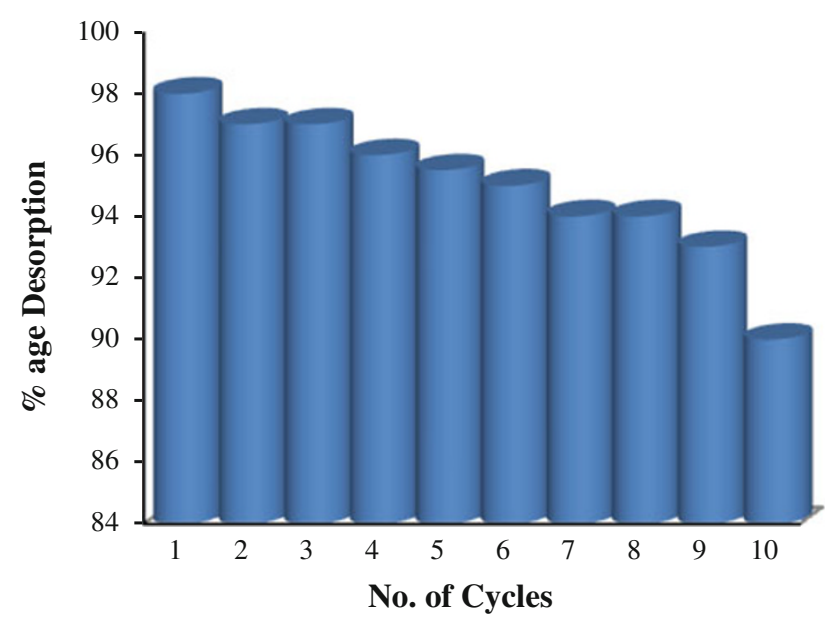

Fig. 8 Reusability of biosorbent with repeated sorption-desorption cycle

of the plot. The $\beta_{\mathrm{L}}$ at $30{ }^{\circ} \mathrm{C}$ was found $0.235 \mathrm{~cm} \mathrm{~s}^{-1}$, respectively. The values indicate that the velocity of the mass transfer in the system is significant; hence, this process is recommended for industrial application.

\section{Desorption efficiency and reusability}

The regeneration of the biosorbent is one of the key factors in assessing of its potential for commercial applications. Two different desorption agents $\left(1 \mathrm{M} \mathrm{HCl}\right.$ and $1 \mathrm{M} \mathrm{HNO}_{3}$ ) were used to desorbe the $\mathrm{Cr}(\mathrm{VI})$ from the biosorbent. The desorption efficiency of $\mathrm{Cr}(\mathrm{VI})$ was found to be 98 and $65 \%$ using $1 \mathrm{M} \mathrm{HCl}$ and $1 \mathrm{M} \mathrm{HNO}_{3}$ respectively. Therefore, $1 \mathrm{M} \mathrm{HCl}$ solution was selected as desorption agent. The reusability of the biosorbent was also tested in 10 consecutive sorption-desorption cycles. The results showed that the biosorbent offers potential to be used repeatedly in $\mathrm{Cr}(\mathrm{VI})$ sequestering process (Fig. 8).

\section{Conclusions}

The potential use of Dalbergia sissoo pods in its various forms as a biosorbent for sequestering of chromium (VI) was studied. This new biosorbent is able to remove the $\mathrm{Cr}(\mathrm{VI})$ ions from aqueous solutions, and the sorption capacity was strongly dependent on the adsorbent nature, the amount used, the initial metal-ion concentration, and the initial $\mathrm{pH}$. The experimental data fitted well to the Freundlich and Langmuir equations, with good correlation coefficients. The experimental data also showed that the process followed a pseudo-second-order equation and both adsorbate and adsorbent were significant in the sorption rate determination. Chromium is adsorbed due to the strong interactions with the active sites of the adsorbent. Further, the utilization of biosorbent impregnated in the form of hydrated beads will also overcome the problem of release of soluble organic materials, while utilizing biomass in its natural form. Moreover, the natural form is not mechanically strong and has a wide size distribution, which can lead to the problems in the operations of reactors by blocking flow lines and clogging filters, while separation of biomass and effluent can be difficult and expensive. Thus, these results can be helpful in designing a wastewater system for the removal of such toxic heavy metal ions. Further work is in progress, in which modifications in the natural form of the biosorbent can lead to the enhanced removal and recovery of the metal ions from aqueous solutions.

Open Access This article is distributed under the terms of the Creative Commons Attribution License which permits any use, distribution, and reproduction in any medium, provided the original author(s) and the source are credited.

\section{References}

Acar FN, Malkoc E (2004) The removal of chromium (VI) from aqueous solutions by Fagusorientalis. Bioresour Techno 94:13-15

Ahluwalia SS, Goyal D (2005a) Removal of heavy metals from waste tea leaves from aqueous solution. Eng Life Sci 5:158-162

Ahluwalia SS, Goyal D (2005b) Microbial and plant derived biomass for removal of heavy metals from waste water. Biores. Technol. 98:2243-2257

Aksu Z (2001) Equilibrium and kinetic modelling of cadmium (II) biosorption by $C$. vulgarisin a batch system: effect of temperature. Sep Purif Technol 21:285-294

Altundogan HS (2005) Cr(VI) removal from aqueous solution by iron (III) hydroxide-loaded sugar beet pulp. Process Biochem 40:1443-1452

Annadurai G, Juang RS, Lee DL (2002) Adsorption of heavy metals from water using banana and orange peels. Water Sci Technol 47:185-190

Bailey SE, Olin TJ, Bricka RM, Adrian DD (1999) A review of potentially low-cost sorbents for heavy metals. Water Res 33:2469-2479

Bassco MC, Cerrella EG, Cukierman AL (2002) Lignocellulosic materials as potential biosorbents of trace toxic metals from wastewater. Chem Res 41:3580-3585

Beveridge TJ, Murray RGE (1980) Sites of metal deposition in the cell wall of Bacillus subtilis. J Biotechnol 141:876-887

Bishnoi NR, Bajaj M, Sharma N, Gupta A (2004) Adsorption of chromium (VI) on activated rice husk carbon and activated alumina. Bioresour Technol 91:305-307

Cieslak-Golonka M (1995) Toxic and mutagenic effects of chromium (VI): a review. Polyhedron 15:3667-3689

Cimino G, Passerini A, Toscano G (2000) Removal of toxic cations and $\mathrm{Cr}(\mathrm{VI})$ from aqueous solution by hazelnut shell. Water Res 34:2955-2962

Dahbi S, Azzi M, Guardia M (1999) Removal of hexavalent chromium from wastewaters by bone charcoal. Fresenius J Anal Chem 363:404-407

Demirbas A (2000a) Biomass resources for energy and chemical industry. Energy Edu Sci Technol 5:21-45 
Demirbas A (2000b) Recent advances in biomass conversion technologies. Energy Edu Sci Technol 6:19-40

Demirbas A (2005) Estimating of structural composition of wood non-wood biomass samples. Energy Sources 27:761-767

Fahim NF, Barsoum BN, Eid AE, Khalil MS (2006) Removal of $\mathrm{Cr}(\mathrm{III})$ from tannery wastewater using activated carbon from sugar industrial waste. J Hazard Mater 136:303-309

Farajzadeh MA, Monji AB (2004) Adsorption characteristics of wheat bran towards heavy metal cations. Sep Purifi Technol 38: 197-207

Gardea-Torresdey JL, Tiemann KJ, Armendariz V, Bess-Oberto L, Chianelli RR, Rios J, Parsons JG, Gamez G (2000) Characterization of chromium (VI) binding and reduction to chromium (III) by the agricultural byproduct of Avena monida (oat) biomass. J Hazard Mater B 80:175-188

Garg VK, Gupta R, Kumar R, Gupta RK (2004a) Adsorption of chromium from aqueous solution on treated sawdust. Bioresour Technol 92:79-81

Garg VK, Gupta R, Kumar R, Gupta RK (2004b) Adsorption of chromium from aqueous solution on treated sawdust. Biores. Technol. 92:79-81

Garg UK, Kaur MP, Garg VK, Sud D (2007) Removal of hexavalent chromium from aqueous solution by agricultural waste biomass. J Hazard Mater 140:60-68

Garg UK, Kaur MP, Garg VK, Sud D (2008) Removal of Ni (II) from aqueous solution by adsorption on agricultural waste biomass using a response surface methodological approach. Bioresour Technol 99:1325-1331

Goel J, Kadirvelu K, Rajagopal C, Garg VK (2005) Removal of lead (II) by adsorption using treated granular activated carbon: batch and column studies. J Hazard Mater B125:211-220

Gupta VK, Ali I (2004) Removal of lead and chromium from wastewater using bagasse fly ash-a sugar industry waste. J Colloid Interface Sci 271:321-328

Gupta VK, Mohan D, Sharma S, Park KT (1999) Removal of Cr VI from electroplating industry wastewater using bagasse fly ash. Environmentalist 19:129-136

Hamadi ND, Chen XD, Farid MM, Lu MGQ (2001) Adsorption kinetics for the removal of chromium (VI) from aqueous solution by adsorbents derived from used tyres and sawdust. Chem Eng $\mathrm{J}$ 84:95-105

Hashem A, Abdel-Halim ES, El-Tahlawy KF, Hebeish A (2005) Enhancement of adsorption of $\mathrm{Co}$ (II) and $\mathrm{Ni}$ (II) ions onto peanut hulls though esterification using citric acid. Adsorp Sci Technol 23:367-380

Hashem A, Abou-Okeil A, El-Shafie A, El-Sakhawy M (2006) Grafting of high $\alpha$-cellulose pulp extracted from sunflower stalks for removal of $\mathrm{Hg}(\mathrm{II})$ from aqueous solution. Polymer-Plastics Technol Eng 45:135-141

Ho YS, Mckay G (1998) Kinetic models for the adsorption of dye from aqueous solution by wood. J Environ Sci Health 76:183-187

Kapoor A, Viraraghavan T, Cullimore DR (1999) Removal of heavy metals using the fungus Aspergillus niger. Bioresour Technol 70:95-104

Karthikeyan T, Rajgopal S, Miranda LR (2005) Chromium (VI) adsorption from aqueous solution by Heveabrasilinesis sawdust activated carbon. J Hazard Mater B124:192-199

Kowalski Z (1994) Treatment of chromic tannery wastes. J Hazard Mater 37:137-144

Koynucu H (2008) Adsorption kinetics of 3-hydroxy benzaldehyde on native and activated bentonite. Appl Clay Sci 38:279-282

Krishanani KK, Parmila V, Meng X (2004) Detoxification of chromium (VI) in coastal water using lignocellulosic agricultural waste. Water SA 30:541-545
Macchi G, Marani D, Tirivanti G (1986) Uptake of mercury by exhausted coffee grounds. Environ Technol Lett 7:431-444

Mohan D, Singh KP, Singh VK (2006) Trivalent Cr removal from wastewater using low cost activated carbon derived from agricultural waste material and activated carbon fabric cloth. J Hazard Mater B 135:280-295

Mohanty K, Jha M, Biswas MN, Meikap BC (2005) Removal of chromium (VI) from dilute aqueous solutions by activated carbon developed from Terminalia arjuna nuts activated with zinc chloride. Chem Eng Sci 60:3049-3059

Mohanty K, Jha M, Meikap BC, Biswas MN (2006) Biosorption of $\mathrm{Cr}(\mathrm{VI})$ from aqueous solutions by Eichhornia crassipes. J Chem Eng 117:71-77

Namasivayam C, Kadirvelu K, Kumuthu M (1998) Removal of direct red and acid brilliant blue by adsorption on to banana pith. Bioresour Technol 64:77-79

Oliveira EA, Montanher SF, Andnade AD, Nobrega JA, Rollemberg MC (2005) Equilibrium studies for the sorption of chromium and nickel from aqueous solutions using raw rice bran. Process Biochem 40:3485-3490

Orhan Y, Bujukgungor H (1993) The removal of heavy metals by using agricultural wastes. Water Sci Technol 28:247-255

Patterson JW (1977) Waste water treatment. Science Publishers, New York

Qaiser S, Saleemi AR, Ahmad MM (2007) Heavy metal uptake by agro based waste materials. Environ Biotechnol 10:409-416

Rao M, Parwate AV, Bhole AG (2002) Removal of Cr and Ni from aqueous solution using Bagasse and fly ash. Waste Manage $22: 821-830$

Reddad Z, Gerente C, Andres Y, Ralet MC, Thibault JF, Cloirec PL (2002) $\mathrm{Ni}(\mathrm{II})$ and $\mathrm{Cd}$ (II) binding properties of native and modified sugar beet pulp. Carbohydrate Polym 49:23-31

Rojas G, Silva J, Flores JA, Rodriguez A, Maldonado H (2005) Adsorption of chromium onto cross-linked chitosan. Sep Purif Technol 44:31-36

Sarin V, Pant KK (2006) Removal of chromium from industrial waste by using eucalyptus bark. Bioresour Technol 97:15-20

Sarkanen KV, Ludwig CH (1971) Lignins-occurance, formation, structure and reactions. Wiley-Interscience, New York

Singh IB, Singh DR (2002) Cr(VI) removal in acidic aqueous solution using iron-bearing industrial solid wastes and their stabilization with cement. Environ Technol 23:85-95

Sjötröm E (1981) Wood chemistry fundamentals and applications. Academic Press, New York

Sud D, Mahajan G, Kaur MP (2008) Agricultural waste material as potential adsorbent for sequestering heavy metal ions from aqueous solutions: a review. Bioresour Technol 99:6017-6027

Tarley CRT, Arruda MAZ (2004) Biosorption of heavy metals using rice milling byproducts. Characterization and application for removal of metals from aqueous effluents. Chemosphere 54:987-995

Tee TW, Khan RM (1988) Removal of lead, cadmium and zinc by waste tea leaves. Environ Technol Lett 9:1223-1232

Tiravanti G, Petrluzzelli D, Passino R (1997) Pretreatment of tannery wastewaters by an ion exchange process for $\mathrm{Cr}(\mathrm{III})$ removal and recovery. Water Sci Technol 36:197-207

Valix M, Cheung WH, Zhang K (2006) Role of heteroatom in activated carbon for the removal of hexavalent $\mathrm{Cr}$ from wastewater. J Hazard Mater 135:395-405

Venkateswarlu P, Ratnam MV, Rao DS, Rao MV (2007) Removal of chromium from aqueous solution using Azadirachta indica (neem) leaf powder as an adsorbent. Int J Phys Sci 2:188-195

Zhang L, Zhao L, Yu Y, Chen C (1998) Removal of lead from aqueous solution by non-living Rhizopus nigrican. Water Res 32:1437-1444 